\title{
La libranza: una mirada actual, más allá de la ley 1527 del $2012^{*}$
}

The payment order: a current look beyond law 1527 of 2012

Edwin Alexander Villa Patiño'

Fecha correspondencia:

Recibido: 4 de febrero de 2019.

Revisión: 2 de julio de 2019.

Aceptado: 17 de octubre de 2019

Forma de citar:

Villa, Edwin Alexander. La libranza:

una mirada actual, más allá de

la ley 1527 del 2012. Revista CES

Derecho. Vol. 10, No. 2, julio -

diciembre de 2019, 535-565.

Open access

Términos de uso

Licencia creative commons

Etica de publicaciones

Revisión por pares

Gestión por Open Journal System

DOl: http://dx.doi.org/10.21615/

cesder.10.2.1

ISSN: 2145-7719

Sobre el artículo:

* Artículo de revisión, realizado para optar por el título de abogado de la Universidad de Antioquia.

Asesorado por la docente Sandra Eliana Cataño.

Sobre los autores:

1. Estudiante de Derecho $X$

Semestre, Universidad de

Antioquia. Miembro activo del

Semillero de Contratación Privada Contemporánea.

\section{Resumen}

El presente artículo de revisión pretende desarrollar aspectos relacionados con la libranza mediante el cual un pensionado, contratista o empleado adquiere bienes y servicios y autoriza el descuento directo de su pensión, salario o remuneración. El punto de partida es la Ley 1527 de 2012, por la cual se dictó el marco legal detallado de las operaciones de libranza; sin embargo, otras entidades como la Superintendencia de Sociedades, la Superintendencia Financiera de Colombia y la Corte Constitucional, se han manifestado respecto al funcionamiento de esta figura. Por lo tanto, al tener una diversidad de fuentes se analizará más a fondo la libranza en Colombia y se plantearán reflexiones sobre algunos puntos específicos.

Palabras Clave: Libranza, operador de libranza, convenio de recaudo, capacidad de pago, mínimo vital y Ley 1527 de 2012.

\section{Abstract}

This review article aims to develop aspects associated with the payment order, by which a pensioned person, a contractor or an employee acquires goods and services, and authorizes the direct discount from their pension, salary or remuneration. Law 1527 of 2012 is the starting point, by which the detailed legal framework of payment order operations was enacted. Nevertheless, other entities such as the Superintendence of Corporations, the Colombia's Financial Superintendence and the Constitutional Court, have expressed themselves regarding the functioning of this body. Hence, by having a diversity of sources, payment order in Colombia will be analyzed more deeply and considerations as to some specific points will be suggested.

Keywords: Payment order, payment order operator, collection agreement, ability to pay, vital minimum and Law 1527 of 2012.

\section{Sumario}

Introducción. 1. Caracterización de la libranza. 2. La libranza en Colombia. 3. Aspectos problemáticos de la libranza. 4. Decisiones de la Corte Constitucional sobre libranza en sede de tutela. 5. Conclusiones. 6. Referencias.

\section{Introducción}

La libranza se ha convertido en un mecanismo de pago relevante para la adquisición de bienes y servicios por parte de aquella población asalariada, contratista y pensionada con ingresos bajos, aunque constantes. Esto se 
debe a la modalidad de descuento directo en relación con la remuneración o salario del deudor, puesto que facilita los trámites de pago y brinda a la entidad a favor de quien se realiza el descuento, una mayor facilidad de recaudo.

A pesar de lo reciente de la Ley 1527 de 2012, la libranza se ha ejecutado con anterioridad en aplicación del Código Sustantivo del Trabajo, bajo la figura de los descuentos autorizados. La ley en mención brindó a quienes utilizan la figura un marco de seguridad y certeza sobre las condiciones necesarias para realizar de forma legal y segura la operación, situación que ha facilitado que el crecimiento de este mecanismo aumente en el contexto colombiano, como será referido más adelante.

El presente artículo tendrá como tema central una mirada holística que comprenda lo relacionado con los requisitos de creación y desarrollo de la libranza, así como algunas tensiones prácticas que genera dicho mecanismo. En tal sentido, se analizará no sólo la norma, Ley 1527 del 2012, sino también los pronunciamientos de la Superintendencia de Sociedades, Superintendencia Financiera y algunos datos de las Administradoras de Fondos de Pensiones. Sobre este último punto, no hay cifras públicas sobre las pensiones que a la fecha se encuentran afectadas con libranza que den cuenta de la realidad de este mecanismo en el campo pensional, de manera que este aspecto se constituye en un plus del presente escrito. Para finalizar con una alusión a las sentencias que, en sede de tutela, ha proferido la Corte Constitucional sobre la libranza, tanto anteriores como posteriores a la entrada en vigencia de la Ley 1527 de 2012.

\section{Caracterización de la tibranza}

La libranza es una convención privada mediante la cual un asociado a una cooperativa o una precooperativa, asalariado, pensionado o contratista, autoriza para que de su salario, pensión u honorarios le sea descontado de forma directa por el pagador un valor con destino al pago de bienes o servicios que adquirió; dichos pagos serán girados a la entidad operadora de libranza. La definición legal está contenida en la Ley 1527 del año 2012, artículo $1^{\circ}$, modificado por el artículo $1^{\circ}$ de la Ley 1902 de 2018, en los siguientes términos:

El objeto de la libranza es posibilitar la adquisición de productos y servicios financieros o bienes y servicios de cualquier naturaleza, acreditados con el salario, los pagos u honorarios o la pensión, siempre que medie autorización expresa de descuento dada al empleador o entidad pagadora, quien en virtud de la suscripción de la libranza o descuento directo otorgada por el asalariado, contratista o pensionado, estará obligada a girar los recursos directamente a la entidad pagadora.

La Superintendencia Financiera en Concepto 2008038709-002 del 7 de julio de 2008, expresa que la libranza es un "mecanismo de recaudo de cartera" mediante el cual un deudor autoriza a su empleador para que realice un descuento de su salario para atender obligaciones adquiridas con un tercero. Se destaca la importante apreciación que realiza la Superintendencia en dicho concepto, al establecer la necesidad de la existencia de dos convenciones, formando entre ellas una relación de interdependencia, a saber: 
a) El de mutuo entre el acreedor y el deudor-empleado, previo estudio sobre la capacidad de pago y de descuento del deudor, el cual comúnmente se instrumenta e incorpora en un título valor en el que se fijan las condiciones, tales como el monto, el plazo, la tasa de interés, la cuota mensual que debe ser descontada, y

b) Un convenio de recaudo entre el acreedor y el empleador en el que se estipulan, usualmente, aspectos como el que las deducciones se realicen con la respectiva autorización del empleado conforme a las normas laborales, los eventos en que puede ser revocada o no la autorización, la responsabilidad del empleador de verificar previamente que los descuentos se efectúen de acuerdo a los parámetros contenidos en las normas del Código Sustantivo del Trabajo, el procedimiento a seguir en caso de que éstos no se realicen y el plazo para la entrega de las sumas recaudadas. (Superintendecia Financiera de Colombia, 2008).

En la celebración y ejecución de la libranza intervienen tres sujetos: i) deudor o beneficiario, quien es el empleado, asociado, contratista o pensionado que adquiere el bien o servicio y brinda la autorización expresa e irrevocable para el descuento directo de su salario, honorarios o pensión; ii) entidad pagadora, es la persona natural o jurídica o administradora de pensiones y cesantías que tenga a su cargo el pago del salario o la mesada pensional y, por lo tanto, es la llamada a realizar el respectivo descuento; y iii) Entidad operadora, la cual puede estar o no autorizada para administrar recursos del público y es destinataria final de los descuentos realizados ${ }^{1}$. En términos del literal c del artículo 2 de la Ley 1527 de 2012, modificado por la Ley 1902 de 2018, esta última.

Es la persona jurídica o patrimonio autónomo conformado en desarrollo del contrato de fiducia mercantil, que realiza operaciones de créditos que se recaudan a través del mecanismo de libranza, por estar autorizada legalmente para el manejo del ahorro del público o para el manejo de los aportes o ahorros de sus asociados. También podrán ser operadoras aquellas personas jurídicas que sin contar con la mencionada autorización de manejo realizan tales operaciones disponiendo de sus propios recursos o a través de mecanismos de financiamiento autorizados por la ley. En estos casos deberá estar organizada como entidad vigilada por la Superintendencia Financiera de Colombia habilitada para otorgar créditos, o ser Instituto de Fomento y Desarrollo (Infis), una Caja de Compensación Familiar, una sociedad comercial, una asociación mutual o cooperativa².

Con la reciente expedición de la Ley 1902 de 2018 se amplía el margen de entidades operadoras a las asociaciones de pensionados o de personal con asignación de retiro de la Fuerza Pública, a los clubes sociales de oficiales, suboficiales y agentes de la Fuerza Pública exclusivamente para los servicios, bienes y productos que presten de forma directa y para aquellas Instituciones Educativas que presten servicios a familias de miembros de la Fuerza Pública, únicamente para el pago de los emolumentos causados por los servicios educativos prestados.

Es de especial relevancia enunciar lo relativo a la realización de un convenio de recaudo entre la empresa pagadora y la entidad operadora de la libranza, para que las cuotas descontadas del salario, honorarios o pensión sean trasladadas al destinatario final y la

1. La Superintendencia de Sociedades en Oficio 220-115349 del 06 de junio de 2017 expresa que las empresas industriales y comerciales no pueden ostentar tal calidad, por la naturaleza propia que poseen.

2. En el mismo sentido Oficio 220-158289 del 23 de septiembre de 2014 emitido por Supersociedades. 
forma en la que esto se debe verificar. Señala la Superintendencia de Sociedades que, "frente a la inexistencia del acuerdo o convenio, el crédito otorgado, no cumpliría las especificaciones legales previstas para el crédito en la modalidad de libranza" (Superintendencia de Sociedades, 2016). Dicho convenio de recaudo se convierte entonces en un elemento fundamental a la hora de referirse a la existencia de la libranza.

Para las partes de la libranza surgen obligaciones claras de la normatividad que regula la libranza, contenidas en la Ley 1527 del 27 de abril 2012, Ley 1902 del 22 de junio de 2018, Decreto 1881 de 2012, Decreto 1455 de 2013 y Decreto 1348 de 2016. Teniendo como punto de partida la normativa anteriormente señalada y el documento denominado ABC de las Libranzas, realizado por la Procuraduría General de la Nación en el año 2017, las obligaciones de las partes se enunciarán a continuación.

Para la entidad operadora, las cuales son reseñadas de forma mayoritaria en el artículo 5 de la Ley 1527 de 2012:

- Estar inscrita en el Registro Único Nacional de Entidades Operadoras de Libranza -RUNEOL-. (excepto las Instituciones Educativas que le presten servicios a familias de miembros de la Fuerza Pública, artículo 2, literal C de la Ley 1902 de 2018).

- Respetar los derechos de los beneficiarios.

- Tener en cuenta la capacidad de endeudamiento del solicitante.

- Asumir la responsabilidad de evaluar con el empleador el monto del descuento directo compuesto por el capital y la tasa de interés pactada. Este monto no debe superar el $50 \%$ del salario neto o pensión después de los descuentos de Ley.

- Dejar a disposición de los beneficiarios el extracto periódico de su crédito con una descripción detallada del mismo, indicándole un número de teléfono y dirección electrónica en caso de dudas o reclamos.

- Reportar la suscripción de la libranza a los bancos de datos de información financiera, crediticia, comercial y de servicios, de conformidad con lo establecido en la Ley.

- No incluir dentro de la libranza valores diferentes al capital e interés y recaudo del seguro de vida deudores, cuando éste exista.

- Diligenciar el pagaré únicamente por el capital efectivamente prestado, sin incluir en él: el valor de aportes, el valor de servicios adicionales o los dineros para fondos mutuales.

- Informar en todo momento sobre las condiciones en las que se suscribe la libranza.. (Procuraduría General de la Nación, 2017, p. 7).

Asunto que también es dilucidado por la Superintendencia de Sociedades en el Oficio 220-024107 del 06 de marzo de 2013 en el cual se exponen los requisitos para la conformación de una sociedad operadora de libranza3.

3. "e) En resumen, tenemos que para que una entidad o sociedad pueda realizar operaciones de crédito bajo la modalidad de libranza o descuento directo, deberá cumplir, entre otros, los siguientes requisitos: 
Es menester diferenciar cuándo se está ante una entidad operadora de libranza, la cual debe cumplir con los requisitos antes enunciados, y cuándo en el escenario de una simple autorización de descuento que no configura para el ente jurídico la actividad comercial de operador de libranza, sino un simple descuento autorizado que se debe regir por las normas laborales, tal y como lo señala López Cárdenas (2015, p. 143). Por lo tanto, no siempre que haya un descuento por nómina se presenta la figura de libranza. Al respecto, la Superintendencia de Sociedades en concepto 220-168212 del 03 de agosto de 2017 da luces para resolver tal situación, al señalar que no se está ante un operador de libranza sí: a) los servicios son prestados sólo a sus trabajadores y b) los ingresos por dicha actividad no corresponden a la mayoría de sus ingresos. Contrario sensu, estamos ante una entidad operadora de libranza cuando:

En todo caso, de llegar a establecerse que los ingresos de la compañía se generen mayormente, por la actividad de libranza o descuento directo de nómina y, además, que tal actividad la cumple también en beneficio de personas que son ajenas a la misma, se estaría ahí sí en presencia de una entidad operadora de libranza.

La misma Superintendencia, pero esta vez a través del oficio 220-121536 del 03 de septiembre de 2013, indica que una entidad operadora de libranza puede ser a la vez operadora y entidad pagadora, toda vez que de la normatividad no se desprende una prohibición para obtener la doble calidad.

- A su turno, las obligaciones para la entidad pagadora son:

- Girar de manera directa los recursos a la entidad operadora de libranza a nombre del beneficiario.

- No negarse injustificadamente a la suscripción del acuerdo entre operador y beneficiario. Sin embargo, dicha suscripción podrá negarse una vez evaluada la capacidad de descuento del beneficiario.

- Efectuar las libranzas y trasladar dichas cuotas a las entidades operadoras dentro de los tres (3) días hábiles siguientes de haber efectuado el abono al asalariado, contratista, afiliado, asociado o pensionado, en el mismo orden cronológico en que haya recibido la libranza.

- Verificar que la entidad operadora o administradora se encuentra inscrita en el Registro Único Nacional de Entidades Operadores de Libranza.

- Pagar como sanción pecuniaria el doble del valor total descontado por la libranza, en caso de cobrar o descontar cuota de administración o comisión por realizar el descuento o el giro de los recursos.

i) Que se trate de una persona jurídica o patrimonio autónomo conformado en desarrollo de un contrato de fiducia mercantil.

ii) Que se encuentre autorizada para manejar ahorro del público o aportes o ahorros de sus asociados.

iii) Que a pesar de no estar autorizada realice operaciones de libranza con sus propios recursos o a través de mecanismos de financiamiento autorizados por la ley.

iv) Que su naturaleza sea la de una sociedad comercial, mutual, cooperativa o un Instituto de Fomento y Desarrollo, INFIS.

v) Que en su objeto social está especificada la realización de operaciones de libranza y el origen lícito de sus recursos.

vi) Que la entidad operadora esté inscrita en el Registro Único Nacional de Entidad Operadoras de Libranzas, que se lleva ante el Ministerio de Hacienda y Crédito Público, para los efectos previstos en el artículo 14 de la Ley 1527 de 2012

vii) Que esté cumpliendo con sus deberes como comerciante, según su naturaleza.

viii) Que se encuentre inspeccionada, vigilada o controlada por Superintendencia de Financiera, de Economía Solidaria o de Sociedades, según sea el caso.

ix) Que cumpla con los requisitos exigidos en la ley para la constitución de cada uno de los tipos societarios que van a realizar dicha actividad.

x) Que esté cumpliendo con sus deberes de comerciante". 
- Ser solidariamente responsable por el pago de la obligación adquirida por el beneficiario del crédito si no realizó los descuentos por motivos que le sean imputables.

- Ser responsable por los valores dejados de descontar en caso de desconocer la orden de giro y por los perjuicios que le sean imputables por su descuido. (Procuraduría General de la Nación, 2017, p.12).

Y para el beneficiario las obligaciones son:

- Suscribir la autorización del descuento directo de su salario, honorarios o pensión.

- Informar al operador de libranza cuando termine la relación laboral o el cambio de empleador o contratista.

De igual forma, al beneficiario le asisten derechos entre los cuales están los mencionados en el artículo 4 de la Ley 1527 de 2012, sin perjuicio de los que le asistan en calidad de consumidor o consumidor financiero.

- Escoger libre y gratuitamente cualquier entidad operadora para efectuar operaciones de libranza, así como aquella a través de la cual se realiza el pago de su nómina, honorarios o pensión.

- En ningún caso el empleador o la entidad pagadora podrá cobrar o descontar cuota de administración, comisión o suma alguna por realizar el descuento o el giro de los recursos, so pena de ser objeto de una sanción pecuniaria equivalente al doble del valor total descontado por la libranza, el cual le será aplicado por la autoridad correspondiente.

La ejecución de la libranza no se limita a que la única garantía de pago sea el descuento directo del salario, puesto que, aunque no se puede cobrar comisiones o similares por parte de la entidad pagadora o beneficiaria, sí se autoriza adquirir seguros como el de vida grupo deudores y cualquier otro tipo de garantía que en ejecución del principio de autonomía privada pacten las partes.

El hecho de que se pacten seguros de deuda para garantizar el pago de la obligación sujeta a libranza, no solo beneficia a la entidad operadora sino también al beneficiario u obligado, quien no se ve asaltado por circunstancias imprevistas en torno a un posible incumplimiento en el pago; claro está, que este tipo de seguros deben ser concertados y conocidos por los beneficiarios, en cuanto a sus condiciones, requisitos, derechos, obligaciones y precios, como lo indica la Circular Externa Nro.100-0000003 del pasado 22 de julio - Circulas Básica Jurídica - Cap. IX, Num $3^{4}$. (Superintendencia de Sociedades, 2015).

Ante la variedad de sujetos que pueden ser operadores de la libranza, su inspección, control y vigilancia se distribuye entre tres Superintendencias: Superintendencia Financiera, de Economía Solidaria o de Sociedades, según sea el caso.

Son vigilados por la Superintendencia Financiera: "los establecimientos de crédito autorizados para colocar préstamos, incluyendo aquellos en modalidad de libranza.

4. En el mismo sentido la Superintendencia Financiera de Colombia Concepto 2012101834-001 del 15 de enero de 2013 
Dichos establecimientos son los bancos, las cooperativas financieras y las compañías de financiamiento, conforme a lo dispuesto en el Estatuto Orgánico del Sistema Financiero". (Procuraduría General de la Nación, 2017, p.13).

Por la Superintendencia de Economía Solidaria: "las cooperativas, fondos de empleados y asociaciones mutuales, excepto las que realizan actividades de salud, transporte y vigilancia privada." (Procuraduría General de la Nación, 2017, p.13).

Y, por último, por la Superintendencia de Sociedades:

Aquellas entidades que estén constituidas como sociedades comerciales, que no estén bajo la vigilancia de la Superintendencia Financiera de Colombia o de la Superintendencia de la Economía Solidaria, y que otorguen créditos con recursos propios o a través de mecanismos de financiamiento autorizados por la ley. (Procuraduría General de la Nación, 2017, p. 14)

Con la salvedad, en este último caso, que su control de forma prevalente es sobre temas societarios y no sobre la actividad de libranza propiamente dicha.

Este es un tema complejo ya que fue uno de los factores que influyó en la consumación del escándalo de las libranzas, en el cual, grandes sociedades como ESTRAVAL actuaron de forma irregular mediante operaciones relacionados con la libranza; lo que derivó en que tres de sus más altos dirigentes "aceptaran cargos por captación masiva y habitual de dinero y enriquecimiento ilícito, falsedad y estafa agravada" (Dinero, 2017). Las condiciones de tal actuación ilegal se reseñaron por la prensa local así:

Fueron 4.604 personas las que se presentaron como víctimas de Estraval, la denominada pirámide que se construyó sobre la base de pagarés de libranzas falsos y que prometía rendimientos en tasas de interés que superaban las capacidades del rey Midas. Según la Fiscalía, a un inversionista le prometían hasta $22 \%$ de ganancias por los intereses, cifras que triplicaban lo que podían conseguir en el sistema bancario tradicional. Por eso las autoridades no dudaron en calificar que el negocio de Estraval era un mercado a la sombra en el que, a hoy, hay más de $\$ 495.000$ millones perdidos. (El Espectador. 2017).

La firma Estraval construyó lo que las autoridades consideran una pirámide sobre la base de pagarés de libranzas falsos, que prometían rendimientos a tasas de interés que en algunos casos superaban el 20 por ciento. En el caso de esta pirámide, 4.604 personas se declararon como víctimas por un monto estimado en 496.000 millones de pesos. (SEMANA, 2018).

Pese a que en Colombia se ha consagrado un marco normativo sobre las condiciones de realización de la libranza y de la cesión de créditos derivados de la misma, fue precisamente que las sociedades comerciales implicadas no se encontraban bajo la vigilancia y control de ninguna Superintendencia para la actividad de libranza que dicho entramado ilegal se aprovechó; sólo eran vigiladas en temas societarios por la Superintendencia de Sociedades, pero cumplían a cabalidad con los requisitos para ser sociedades legalmente constituidas. Así lo destaca ASOBANCARIA:

Factores como: (i) la indebida gestión en la organización, (ii) la venta de los créditos respaldados con libranzas por parte de entidades comerciales no vigiladas 
como Estraval y (iii) la falta de vigilancia y control han deteriorado la imagen del descuento directo o libranza y han permitido el uso abusivo de esta figura, minando la seguridad y la confianza del público sobre la actividad financiera. (ASOBANCARIA, 2016, p.1)

Conscientes de lo anterior, con la Ley 1902 de 2018 se modificó el inciso segundo del artículo 10 de la Ley 1527 de 2012 al otorgar competencia residual a la Superintendencia de Industria y Comercio para la protección al consumidor en las operaciones realizadas por operadoras de libranza, siempre que dicha vigilancia no haya sido atribuida a otra autoridad administrativa.

\section{La tibranza en Colombia}

El marco normativo de la libranza en Colombia está conformado por la Ley 1527 del 27 de abril 2012, ley de las operaciones de libranza, la Ley 902 de 2018, el Decreto 1881 de 2012 y el Decreto 1455 de 2013 los cuales hacen referencia a la entrada en vigencia del RUNEOL y el Decreto 1348 de 2016 el cual surge como necesidad de regular el comercio de los pagarés fruto de operaciones de libranza. Se aclara que, antes de la entrada en vigencia de la mencionada ley no existía un marco normativo que permitiría llevar a cabo, con claridad, las operaciones de libranza, sólo una escueta referencia en la Ley 920 de 2004 en su artículo $4^{5}$ y en el artículo 149 del Código Sustantivo del Trabajo.

Como proyecto de ley fue presentado el 26 agosto de 2010 por los congresistas Simón Gaviria Muñoz, David Alejandro Barguil Assis, Eduardo Crissien Borrero y Nicolás Antonio Jiménez Paternina, y fue nombrado como el 066 del año 2010 en Cámara y 280 de 2011 en Senado. Los motivos que adujeron para dicho proyecto de ley fueron:

Varios aspectos propios de los beneficios del crédito de libranza nos inducen a presentar esta iniciativa hoy, entre ellos la posibilidad real de dinamizar en Colombia, el mercado de alquiler y adquisición de vivienda y el acceso a créditos educativos y bienes de consumo básico, entre ellos planes complementarios de salud, auxilios funerarios, electrodomésticos, vehículos, viajes, etc., a través de la masificación de este tipo de crédito que otorga la posibilidad real no sólo a los trabajadores asalariados sino a los pensionados a adquirir bienes y servicios respaldados por su salario, sus prestaciones sociales o su pensión, dentro de los parámetros que sobre el particular ha fijado la Corte Constitucional.

La experiencia internacional en el uso de este mecanismo ha sido increíblemente exitosa esperamos que el honorable Congreso de la República sea receptivo a esta propuesta que fácilmente puede contribuir de manera significativa con el mejoramiento de la calidad de vida de nuestra clase trabajadora y de los pensionados de nuestro país. (Congreso de la República de Colombia, 2010)

Además, al analizar la regulación dispuesta en otros ordenamientos jurídicos y las experiencias significativas de Brasil, donde se le conoce como "ley de Crédito Consignado o Crédito Inmobiliario Consignado" y Panamá, donde ha sido denominada "ley de Descuento Directo". Resaltan:

5. Artículo $4^{\circ}$. Toda persona, empresa o entidad pública o privada, estará obligada a deducir y retener de cualquier cantidad que haya de pagar a sus trabajadores o pensionados, las sumas que estos adeuden a la caja de compensación o cooperativa o fondos de empleados, cuya obligación conste en libranza, títulos valores, o cualquier otro documento suscrito por el deudor quien para el efecto deberá dar su consentimiento previo. En ningún caso las personas y entidades señaladas en este artículo podrán cobrar cuota de administración o suma alguna por realizar esta operación. 
[L]a experiencia con la libranza no es menos importante, Asobancaria nos informa que tan sólo entre julio de 2005 y julio de 2009 las entidades financieras sin incluir BBVA donde el $60 \%$ de la cartera de consumo lo representa la libranza, HNB Sudameris, ni Bancoldex, y aún durante ese lapso se desembolsaron 15.4 billones de pesos en libranza. (Congreso de la República de Colombia, 2010).

En referencia a la constitucionalidad de la Ley 1527 de 2012, ha sido objeto de varias demandas de inconstitucionalidad, a saber: la sentencia C-015 de $\mathbf{2 0 1 3}$ en donde se demandó el artículo 15 de forma parcial, declarándose inexequible por violación al principio de unidad de materia; la C-085 de 2013, se demanda de igual forma el artículo 15 por violación al principio de unidad de materia y se decide estar a lo resuelto en la C 015 de 2013; la C-122 de 2013, en esta oportunidad se demandan por inconstitucionales los artículos 13 y 15 parcial, se profiere fallo inhibitorio puesto que las normas habían sido derogadas o subrogadas por disposiciones posteriores; y, finalmente, la C-751 de 2013, en donde se demanda por vicios formales (ausencia de debate del articulado) y porque su contenido está en contravía de la clase trabajadora, se desestima lo segundo y se resuelve declarar la exequibilidad puesto que fue adecuado el trámite dado al proyecto de ley en el Congreso. Es muy poco lo que se aporta desde el punto de vista sustancial a la discusión. Recientemente se profirió la sentencia C-032 de $\mathbf{2 0 1 8}$, cuyo sentido del fallo fue inhibitorio, puesto que los argumentos del accionante se centran en la presunta vulneración del principio de irrenunciabilidad a los beneficios mínimos establecidos en las normas laborales (art. 53 C.P.), sin embargo, los cargos carecían de certeza, eran inespecíficos y eran insuficientes.

En relación con aspectos financieros, la libranza es una modalidad de crédito de microconsumo de gran aceptación entre los consumidores financieros. Comprende varias modalidades: educativa, de libre inversión, cupo rotativo, para adquisición de vivienda, entre otros.

Para el año 2015 la modalidad de créditos de consumo alcanzaba el 26.6\% de la totalidad de los créditos en Colombia y de ese porcentaje, el 36,5\% correspondía a la modalidad de libranza. La demanda de la libranza pasa del 21.9\% (8.9 Billones) en el año 2008 al 36.5\% (36.4\%) para el 2015. En igual sentido lo expresa el Banco de la República en informe de 2017 :

Por su parte, la composición del saldo se mantiene en niveles similares a los observados en reportes anteriores, donde la modalidad de libranza es la que más peso tiene $(36,1 \%)$, seguida de libre inversión (24,0\%), tarjetas de crédito $(21,3 \%)$, vehículos $(11,3 \%)$, crédito rotativo $(5,2 \%)$ y otros portafolios de consumo (2,1\%). (Banco de la República, 2017, p.7).

Su importante participación en la línea de créditos de consumo también es destacada por ASOBANCARIA (2016), así: "A nivel de entidades, la modalidad de libranza tiene una alta concentración en los bancos Multibank (99,7\%), Popular (97,8\%), GNB Sudameris (94\%) y Agrario (65,9\%)". (p. 35).

La misma entidad respecto a la libranza, a marzo de 2016, "indicó que abarcaba un total de 36.4 billones de pesos y "el valor promedio de cada crédito que ha venido creciendo a lo largo de los últimos años, ahora bordea los $\$ 25$ millones" (ASOBANCARIA, 2016, p. 4). 
Este crecimiento de la libranza se atribuye a factores como:

- Seguridad jurídica con la expedición de la Ley 1527 de 2012, puesto que antes de esta norma se basaba en el principio de la autonomía privada.

- Retención del dinero en la fuente del ingreso, siendo la Administradora de Fondos de Pensiones (AFP), empleador o contratista el encargado de realizar el respectivo descuento.

- Recaudo centralizado, lo que no genera un riesgo extra para las entidades operadoras al ser deducido de la fuente. Asunto que se verifica con lo expresado en el informe del Banco de la República (2017), al exponer los créditos con menor índice de mora: "Por su parte, la de libranza es la que presentó un mejor indicador (2,6\%)" (p. 8).

- Certeza sobre la información, ubicación e ingresos del beneficiario o usuario.

- Se reduce la discrecionalidad en el pago, puesto que se pone de presente un piso máximo del $50 \%$ neto del salario.

Ahora bien, respecto a los datos actuales de la libranza en Colombia en materia pensional, como parte del proceso investigativo para la elaboración de este escrito, se presentaron derechos de petición a los cinco fondos encargados de pensiones, los cuatros del Régimen de Ahorro Individual (RAIS) y a Colpensiones como entidad del Régimen de Prima Media (RPM), los cuales, de forma semejante, afirmaron inicialmente la reserva de la información, por lo que se tuvo que acudir a la acción de tutela para la protección del derecho de acceso a la información y del derecho de petición; no obstante, de las cuatro tutelas presentadas, tres fueron falladas de forma favorable y una desfavorable. Sobre la última, es menester resaltar que se estaba ante los mismos supuestos y argumentos, sin embargo, el juez decidió de modo diferente.

Los datos obtenidos fueron los siguientes:

\section{- $\quad$ Por parte de PORVENIR S.A}

Todos los datos que se reseñan para PORVENIR S.A. fueron obtenidos con corte al 19 de febrero de 2018. Respecto a las pensiones causadas y vigentes:

Tabla 1. Pensiones totales a cargo del fondo PORVENIR S.A

\begin{tabular}{cc}
\hline Etiquetas de fila & Cuenta por pagar \\
\hline Vejez & 15706 \\
Sobrevivencia & 9645 \\
Invalidez & 2730 \\
Total general & $\mathbf{2 8 0 8 1}$ \\
\hline
\end{tabular}


Con referencia a las solicitudes de libranza recibidas, discriminadas por tipo de pensión:

Tabla 2. Solicitudes de libranza recibidas por PORVENIR S.A

\begin{tabular}{ccccc}
\hline Etiquetas de fila & Vejez & Sobrevivencia & Invalidez & Total general \\
\hline 2011 & 6 & $X$ & $X$ & 6 \\
2012 & 17 & 5 & 4 & 26 \\
2013 & 40 & 7 & 10 & 57 \\
2014 & 88 & 48 & 34 & 170 \\
2015 & 217 & 84 & 105 & 406 \\
2016 & 600 & 186 & 222 & 1008 \\
2017 & 1198 & 291 & 321 & 1810 \\
2018 & 280 & 57 & 72 & 409 \\
Total & $\mathbf{2 4 4 6}$ & $\mathbf{6 7 8}$ & $\mathbf{7 6 8}$ & $\mathbf{3 8 9 2}$ \\
\hline
\end{tabular}

Respecto al histórico de solicitudes de libranza recibidas y vigentes:

Tabla 3. Solicitudes de libranzas recibidas y vigentes por parte de PORVENIR S.A

\begin{tabular}{ccc}
\hline Etiquetas de Fila & Cuenta de descuento Adicional & Activas \\
\hline 2009 & 216 & $X$ \\
2010 & 323 & $X$ \\
2011 & 580 & 6 \\
2012 & 795 & 26 \\
2013 & 1073 & 57 \\
2014 & 1256 & 170 \\
2015 & 1696 & 406 \\
2016 & 2178 & 1008 \\
2017 & 2247 & 1810 \\
2018 & 777 & 409 \\
Total General & $\mathbf{1 1 1 4 1}$ & $\mathbf{3 8 9 2}$ \\
\hline
\end{tabular}

Se tiene entonces que de las 28.081 pensiones a cargo de este fondo, 3892 se encuentran gravadas con libranza, lo que corresponde a un $13.85 \%$. De igual forma, del total de pensiones afectadas con libranza, el $62.84 \%$ corresponde a pensiones de vejez.

Según los datos obtenidos al 19 de enero de 2018, las cifras referentes a OLD MUTUAL, son:

- Respecto al total de pensiones que tiene a cargo: 
Fondo de Pensiones Obligatorias

Tabla 4. Pensiones obligatorias a cargo de OLD MUTUAL

\begin{tabular}{ccc}
\hline Evento de Pensión & Retiro Programado & $\begin{array}{c}\text { Retiro Programado sin negociación } \\
\text { del bono pensional }\end{array}$ \\
\hline Invalidez & 111 & 0 \\
Sobrevivencia & 267 & 0 \\
Vejez & 1863 & 475 \\
Total & $\mathbf{2 2 4 1}$ & $\mathbf{4 7 5}$ \\
\hline
\end{tabular}

Fondo de pensiones alternativo

Tabla 5. Pensiones obligatorias a cargo de OLD MUTUAL

\begin{tabular}{ccc}
\hline Evento de Pensión & Retiro Programado & $\begin{array}{c}\text { Retiro Programado sin negociación } \\
\text { del bono pensional }\end{array}$ \\
\hline Invalidez & 1 & 0 \\
Sobrevivencia & 7 & 0 \\
Vejez & 111 & 20 \\
Total & $\mathbf{1 1 9}$ & $\mathbf{2 0}$ \\
\hline
\end{tabular}

Sobre las pensiones afectadas en la actualidad con libranza:

Tabla 6. Pensiones afectadas con libranza a cargo de OLD MUTUAL

\begin{tabular}{lccccccc}
\hline Evento de Pensión & $\mathbf{2 0 1 3}$ & $\mathbf{2 0 1 4}$ & $\mathbf{2 0 1 5}$ & $\mathbf{2 0 1 6}$ & $\mathbf{2 0 1 7}$ & $\mathbf{2 0 1 8}$ & Total \\
\hline Vejez & 5 & 1 & 14 & 30 & 75 & 16 & 141 \\
Invalidez & 0 & 0 & 3 & 8 & 5 & 2 & 18 \\
Sobrevivencia & 0 & 0 & 2 & 3 & 3 & 1 & 9 \\
Total & $\mathbf{5}$ & $\mathbf{0}$ & $\mathbf{1 9}$ & $\mathbf{4 1}$ & $\mathbf{8 3}$ & $\mathbf{1 9}$ & $\mathbf{1 6 8}$ \\
\hline
\end{tabular}

Con referencia al histórico de solicitudes recibidas de libranza:

Tabla 7. Solicitud de libranzas recibidas por OLD MUTUAL

\begin{tabular}{lccccccccc}
\hline Evento de Pensión & $\mathbf{2 0 1 1}$ & $\mathbf{2 0 1 2}$ & $\mathbf{2 0 1 3}$ & $\mathbf{2 0 1 4}$ & $\mathbf{2 0 1 5}$ & $\mathbf{2 0 1 6}$ & $\mathbf{2 0 1 7}$ & $\mathbf{2 0 1 8}$ & Total \\
\hline Invalidez & 0 & 2 & 3 & 2 & 5 & 8 & 6 & 3 & 29 \\
Sobrevivencia & 1 & 3 & 1 & 4 & 2 & 4 & 3 & 1 & 19 \\
Vejez & 6 & 15 & 15 & 22 & 29 & 49 & 82 & 20 & 238 \\
Total & $\mathbf{7}$ & $\mathbf{2 0}$ & $\mathbf{1 9}$ & $\mathbf{2 8}$ & $\mathbf{3 6}$ & $\mathbf{6 1}$ & $\mathbf{9 1}$ & $\mathbf{2 4}$ & $\mathbf{2 8 6}$ \\
\hline
\end{tabular}


Aclarando que de las 286 solicitudes, 168 se encuentra vigentes. A lo que debe sumarse siete solicitudes de libranza sobre pensiones del Fondo Alternativo. Del total de 2855 pensiones a cargo del fondo, 175 se encuentran gravadas con libranza, para un total del $6,13 \%$. De la cantidad total de pensiones afectadas con libranza, 83,92\% son de vejez.

Respecto a los datos recopilados sobre COLFONDOS hasta el 19 de enero de 2018 e iniciado con las pensiones vigentes a la fecha de recolección de los datos, son:

Tabla 8. pensiones a cargo de COLFONDOS

\begin{tabular}{lccc}
\hline \multicolumn{4}{c}{ Modalidad de Pensión } \\
\hline Tipo Pensión & Retiro Programado & Vejez sin negociación bono pensional & Total general \\
\hline Invalidez & 1534 & 0 & 1534 \\
Sobrevivencia & 3813 & 0 & 3813 \\
Vejez & 7825 & 818 & 8643 \\
Total General & $\mathbf{1 3 1 7 2}$ & $\mathbf{8 1 8}$ & $\mathbf{1 3 9 9 0}$ \\
\hline
\end{tabular}

Con referencia a las libranzas vigentes a la fecha mencionada:

Tabla 9. libranzas vigentes a cargo de COLFONDOS

\begin{tabular}{lcccccccc}
\hline \multicolumn{7}{c}{ Año de inicio de descuento de la mesada } \\
\hline Tipo de pensión & $\mathbf{2 0 1 2}$ & $\mathbf{2 0 1 3}$ & $\mathbf{2 0 1 4}$ & $\mathbf{2 0 1 5}$ & $\mathbf{2 0 1 6}$ & $\mathbf{2 0 1 7}$ & $\mathbf{2 0 1 8}$ & Total General \\
\hline Invalidez & 0 & 4 & 24 & 71 & 133 & 235 & 71 & 538 \\
Sobrevivencia & 0 & 8 & 39 & 94 & 195 & 309 & 87 & 732 \\
Vejez & 1 & 4 & 54 & 187 & 382 & 683 & 275 & 1586 \\
Total General & $\mathbf{1}$ & $\mathbf{1 6}$ & $\mathbf{1 1 7}$ & $\mathbf{3 5 2}$ & $\mathbf{7 1 0}$ & $\mathbf{1 2 2 7}$ & $\mathbf{4 3 3}$ & $\mathbf{2 8 5 6}$ \\
\hline
\end{tabular}

Y en relación a la línea histórica de pensiones afectadas con libranza se tiene:

Tabla 10. Año de aplicación de la libranza por parte de COLFONDOS

\begin{tabular}{lccccccccccc}
\hline \multicolumn{110}{c}{ Año de aplicación novedad de libranza } \\
\hline $\begin{array}{l}\text { Tipo de } \\
\text { Pensión }\end{array}$ & $\mathbf{2 0 0 9}$ & $\mathbf{2 0 1 0}$ & $\mathbf{2 0 1 1}$ & $\mathbf{2 0 1 2}$ & $\mathbf{2 0 1 3}$ & $\mathbf{2 0 1 4}$ & $\mathbf{2 0 1 5}$ & $\mathbf{2 0 1 6}$ & $\mathbf{2 0 1 7}$ & $\mathbf{2 0 1 8}$ & $\begin{array}{c}\text { Total } \\
\text { general }\end{array}$ \\
\hline Invalidez & 41 & 72 & 135 & 315 & 309 & 269 & 201 & 238 & 304 & 104 & 1988 \\
Sobrevivencia & 121 & 160 & 208 & 292 & 255 & 310 & 300 & 344 & 394 & 115 & 2499 \\
Vejez & 34 & 54 & 104 & 163 & 236 & 396 & 530 & 691 & 832 & 362 & 3402 \\
Total General & $\mathbf{1 9 6}$ & $\mathbf{2 8 6}$ & $\mathbf{4 4 7}$ & $\mathbf{7 7 0}$ & $\mathbf{8 0 0}$ & $\mathbf{9 7 5}$ & $\mathbf{1 0 3 1}$ & $\mathbf{1 2 7 3}$ & $\mathbf{1 5 3 0}$ & $\mathbf{5 8 1}$ & $\mathbf{7 8 8 9}$ \\
\hline
\end{tabular}

De manera que, para COLFONDOS del total de pensiones que ascienden a 13.990 , 2856 se encuentran afectadas con libranza para un total del 20,4\%. Asimismo, de las pensiones afectadas con libranza el 55,53\% son pensiones de vejez.

A su turno, los datos recopilados hasta el 22 de mayo de 2018 correspondientes a COLPENSIONES, son: 
Pensiones a cargo de la entidad:

Tabla 11. Pensiones a cargo de COLPENSIONES

\begin{tabular}{|c|c|c|}
\hline Grupo Riesgo & Tipo pensión & Pensiones Activas \\
\hline \multirow{2}{*}{ Vejez } & Sustitución & 142.433 \\
\hline & Vejez & 944.891 \\
\hline & Total & 1.087 .324 \\
\hline \multirow{2}{*}{ Invalidez } & Invalidez & 69.195 \\
\hline & Sustitución Invalidez & 27.211 \\
\hline & Total & 96.406 \\
\hline \multirow[t]{2}{*}{ Muerte } & Sobrevivientes & 149.518 \\
\hline & Sustitución Vejez & 2.376 \\
\hline Total & & 151.894 \\
\hline \multicolumn{2}{|c|}{ Total pensiones Colpensiones } & 1.335 .624 \\
\hline
\end{tabular}

Con referencia a las libranzas vigentes al periodo del 2018 reseñado:

Tabla 12. libranzas vigentes a cargo de COLPENSIONES

\begin{tabular}{ccccc}
\hline & Vejez & Invalidez & Muerte & Total General \\
\hline $\begin{array}{c}\text { Prestamos vigentes por riesgo y } \\
\text { por año del préstamo }\end{array}$ & $\mathbf{5 9 1 . 4 4 1}$ & $\mathbf{5 1 . 4 0 8}$ & $\mathbf{7 2 . 0 7 9}$ & $\mathbf{7 1 4 . 9 2 8}$ \\
\hline 2009 & 0 & 0 & 1 & 1 \\
2010 & 143 & 16 & 33 & 192 \\
2011 & 1.691 & 78 & 138 & 1.907 \\
2012 & 8.465 & 523 & 844 & 9.832 \\
2013 & 19.101 & 1.376 & 2.117 & 22.594 \\
2014 & 36.230 & 2.577 & 4.095 & 42.902 \\
2015 & 67.318 & 5.287 & 8.155 & 80.760 \\
2016 & 114.411 & 9.528 & 13.951 & 137.590 \\
2017 & 216.304 & 19.716 & 26.926 & 262.946 \\
2018 & 128.078 & 12.307 & 15.819 & 156.204 \\
Total General & $\mathbf{5 9 1 . 4 4 1}$ & $\mathbf{5 1 . 4 0 8}$ & $\mathbf{7 2 . 0 7 9}$ & $\mathbf{7 1 4 . 9 2 8}$ \\
\hline
\end{tabular}


Por último, con relación al histórico de solicitudes de libranza recibidas:

Tabla 13. número de solicitudes de libranza recibidas por COLPENSIONES

\begin{tabular}{cccc}
\hline Año de préstamo & Invalidez & Muerte & Vejez \\
\hline 2009 & 16.602 & 26.518 & 188.622 \\
\hline 2010 & 17.569 & 27.701 & 206.073 \\
\hline 2011 & 18.047 & 28.718 & 231.305 \\
\hline 2012 & 24.882 & 36.985 & 295.967 \\
\hline 2013 & 23.892 & 36.161 & 299.454 \\
\hline 2014 & 22.228 & 33.813 & 310.519 \\
\hline 2015 & 25.815 & 38.412 & 332.541 \\
\hline 2016 & 29.101 & 41.064 & 343.278 \\
\hline 2017 & 29.695 & 39.653 & 327.418 \\
\hline 2018 & 12.944 & 16.559 & 135.068 \\
\hline Total & $\mathbf{2 2 0 . 7 7 5}$ & $\mathbf{3 2 5 . 5 8 4}$ & $\mathbf{2 . 6 7 0 . 2 4 5}$ \\
\hline
\end{tabular}

De igual forma como se realizó con las tres AFP anteriores, del total de pensiones vigentes a cargo de COLPENSIONES un total de $53,52 \%$ se encuentra afectadas con libranza. Y del total afectado con libranza, el 82,72 \% corresponde a pensiones de vejez.

Como complemento a la información obtenida vía derecho de petición, al consultar el portal web de la Superintendencia Financiera sobre el total de afiliados al sistema de pensiones en el RAIS, en específico de PROTECCIÓN (fondo faltante por suministro de datos) y las pensiones vigentes a febrero de 2018, según portal de la Superintendencia Financiera de Colombia en la sección: Fondos de Pensiones Obligatorias, Afiliados, se tiene:

\begin{tabular}{ll}
\hline Retiro Programado: & 27.960 \\
\hline Renta Vitalicia (todas sus modalidades) & 10.389 \\
\hline Total & $\mathbf{3 8 . 3 4 9}$ \\
\hline
\end{tabular}

Ya que fue la única acción de tutela de la que no se obtuvo respuesta positiva ${ }^{6}$, no se posee la cifra concreta del número de libranzas vigentes.

\section{Aspectos problemáticos de la tibranza}

\section{Negativa a suscribir el convenio de recaudo}

Como se explicó en el primer acápite, son tres las partes de la operación de libranza: deudor, operador de libranza y entidad pagadora, entre los dos últimos se realiza el denominado convenio de recaudo, de vital importancia toda vez que regula lo referente a las condiciones de logística y forma de pago del descuento realizado al deudor de modo directo por el pagador; de no existir tal convenio no se estaría ante

6. Tutela tramitada bajo el radicado 050014088002201800067 . Fallada en forma desfavorable en primera instancia por el Juzgado Segundo Penal Municipal con Función de Control de Garantía y en segunda instancia, el fallo fue confirmado por el Juzgado Veinticinco Penal del Circuito con Funciones de Conocimiento; ambos de la ciudad de Medellín, Antioquia, Colombia. 
una operación de libranza. Dicho convenio siempre tendrá carácter privado, aunque la entidad pagadora sea de naturaleza pública. En términos de la Superintendencia de Sociedades en oficio 220-196557 del 18 de octubre de 2016:

El acuerdo debe establecer las condiciones técnicas y operativas necesarias para la transferencia de los descuentos, por lo que, a juicio de esta Oficina, éste deberá suscribirse por lo menos en forma concomitante a la firma de la libranza con el asalariado, afiliado, contratista, o pensionado, pues el acuerdo presupone que exista el consentimiento previo, expreso, escrito e irrevocable del beneficiario del crédito.

El contrato suscrito entre un asalariado, afiliado, contratista, o pensionado, con una entidad del sector real, cooperativo o financiero, es de naturaleza privada, aunque el empleador o entidad pagadora, tenga naturaleza pública.

La suscripción del convenio en mención constituye una obligación de la entidad pagadora (Art. 6 ley 1527 de 2012) y su omisión o negativa injustificada genera una responsabilidad solidaria de carácter legal, entre la entidad que expresa la negativa y el deudor, frente al operador de la libranza. De igual forma, se establece una responsabilidad solidaria cuando se deja de hacer el descuento, se hace de forma imperfecta o se vulnera el orden de giros (parágrafos 1 y 2 del mismo art. 6). Es necesario señalar que dicho convenio no puede alejarse de las condiciones legales establecidas como marco para la libranza, o actuar como fuente para modificar las obligaciones inicialmente contraídas, estando limitado a aspectos logísticos del recaudo.

Resulta complejo afirmar, de forma taxativa, cuando puede negarse la entidad pagadora a suscribir dicho convenio, no obstante, se puede enunciar lo siguiente: cuando el operador de libranza no se encuentra inscrito en el RUNEOL; al exceder el descuento permitido del $50 \%$ del salario neto; cuando no se cuenta con autorización expresa; o por la existencia de otras libranzas o embargos judiciales que imposibiliten el descuento.

\section{Descuento sobre el salario mínimo y las prestaciones sociales}

El descuento que se realiza es un elemento fundamental en la convención que se analiza, puesto que es el objetivo principal que se persigue. La libranza más que un acuerdo es un instrumento de pago de obligaciones adquiridas previamente. En consecuencia, resulta de obligatoria consulta las disposiciones que consagra el Código Sustantivo del Trabajo en lo referente a los descuentos que se pueden realizar a los salarios de los empleados, en específico los artículos 59,149 y 150 del mencionado código.

ARTICULO 59. Se prohíbe a los empleadores:

1. Deducir, retener o compensar suma alguna del monto de los salarios y prestaciones en dinero que corresponda a los trabajadores, sin autorización previa escrita de éstos para cada caso [subraya fuera del texto], o sin mandamiento judicial, con excepción de los siguientes:

a). Respecto de salarios, pueden hacerse deducciones, retenciones o compensaciones en los casos autorizados por los artículos 113, 150, 151, 152 y 400. 
Sobre el artículo 149:

1. El empleador no puede deducir, retener o compensar suma alguna del salario, sin orden suscrita por el trabajador, para cada caso, o sin mandamiento judicial. Quedan especialmente comprendidos en esta prohibición los descuentos o compensaciones por concepto de uso o arrendamiento de locales, herramientas o útiles de trabajo; deudas del trabajador para con el empleador, sus socios, sus parientes o sus representantes; indemnización por daños ocasionados a los locales, máquinas, materias primas o productos elaborados o pérdidas o averías de elementos de trabajo; entrega de mercancías, provisión de alimentos y precio de alojamiento.

2. Tampoco se puede efectuar la retención o deducción sin mandamiento judicial, aunque exista orden escrita del trabajador, cuando quiera que se afecte el salario mínimo legal o convencional o la parte del salario declarada inembargable por la ley.

3. Los empleadores quedarán obligados a efectuar oportunamente los descuentos autorizados por sus trabajadores que se ajusten a la ley. El empleador que incumpla lo anterior, será responsable de los perjuicios que dicho incumplimiento le ocasione al trabajador o al beneficiario del descuento. (negrilla y subraya fuera de texto)

Es menester señalar que, aunque el art. 149, numeral 2 del CST establece una prohibición de deducción cuando se afecte el salario mínimo legal mensual vigente (SMLMV), por disposición expresa del artículo 3 numeral 5 de la Ley 1527 de 2012. pueden hacerse descuentos al salario mínimo, hasta el 50\% neto, es decir, sin tener en cuenta las deducciones que por ley deben realizarse. Pero dicho monto no fue fácil de determinar ya que se generó una gran discusión en el trámite de aprobación de dicha norma.

En el proceso de aprobación de la Ley 1527 de 2012, segundo debate en Senado, se discutió acerca del límite del descuento, encontrándose posiciones como: la prohibición para aquellos trabajadores que ganaban un salario mínimo, la de aumentar el límite hasta un 70\% del salario neto o un límite que oscilaba entre el 30\% y 50\%. Finalmente, tal y como se reseña en la Gaceta del Congreso No.916, el ponente presentó ponencia con un descuento del 30\% como límite. Posteriormente, en la plenaria del Senado reseñada en la Gaceta 946 de 2011 se decidió con respecto a los descuentos:

5. Que la libranza o descuento directo se efectúe, siempre y cuando el asalariado o pensionado no reciba menos del cincuenta por ciento (50\%) del neto de su salario o pensión, después de los descuentos de ley. Las deducciones o retenciones que realicen el empleador o entidad pagadora, que tengan por objeto operaciones de libranza o descuento directo, quedarán exceptuadas de la restricción contemplada en el numeral 2 del artículo 149 del Código Sustantivo del Trabajo.

El límite dispuesto en el presente numeral se aumentará al setenta por ciento (70\%) del neto del salario o pensión, para aquellos beneficiarios que por dichos conceptos sólo reciban un salario mínimo legal al mes.

7. "5. Que la libranza o descuento directo se efectúe, siempre y cuando el asalariado o pensionado no reciba menos del treinta por ciento (30\%) del neto de su salario o pensión, después de los descuentos de ley. Las deducciones o retenciones que realicen el empleador o entidad pagadora, que tengan por objeto operaciones de libranza o descuento directo, quedarán exceptuadas de la restricción contemplada en el numeral 2 del artículo 149 del Código Sustantivo del Trabajo." (Congreso de la república de Colombia, 2011). 
No obstante, el segundo inciso fue eliminado finalmente.

Sobre los descuentos, estos no se limitan a la vigencia de la relación laboral puesto que también pueden autorizarse sobre las prestaciones sociales, a las que el empleado tiene derecho una vez finalice la relación laboral. Así lo determinó la Superintendencia Financiera, en un concepto, al considerar la necesidad que tienen los profesionales de la actividad crediticia de estudiar el riesgo crediticio de sus clientes, para velar por la recuperación de su dinero, y la facultad de exigir las garantías que consideren necesarias y proporcionales. Puntualmente, el numeral 1.3.2.3.1 del referido concepto, señala que:

(...) el otorgamiento de crédito por parte de tales instituciones debe basarse en el conocimiento del sujeto de crédito o contraparte, de su capacidad de pago (flujos de egresos e ingresos) y de las características del contrato a celebrar entre las partes, que incluyen, entre otros, las condiciones financieras del préstamo, las garantías, fuentes de pago, etc.

Vistas las anteriores consideraciones y bajo la situación expuesta en su comunicación sería factible la exigencia de garantías adicionales o seguridades tales como el respaldo sobre prestaciones sociales u otras indemnizaciones sobre un valor suficiente para cubrir el monto de las correspondientes obligaciones, en tanto no se desconozcan las restricciones legales previstas para disposición de recursos propios con finalidades específicas. (Superintendencia Financiera de Colombia, 2013)

La anterior posición es respaldada por la Superintendencia de Sociedades en oficio 220 - 0002840 del 19 de enero de 2015, así:

Sin embargo, en el evento en que el beneficiario no adquiera una nueva vinculación laboral, contractual o adquiera la condición de pensionado, a juicio de esta Oficina y sin perjuicio obviamente de lo que diga el Ministerio del Trabajo frente al caso en particular, podría el empleador, retener de las sumas de dinero que haya de pagar a sus asalariados, todos los emolumentos que reciba el trabajador como consecuencia de la terminación del contrato.

Lo anterior encuentra también respaldo en el Ministerio de Trabajo mediante oficio 193287 del 30 de septiembre de 2013:

Finalmente y como quiera que la ley 1527 de 2012 no reguló lo referente a los descuentos a la liquidación final de salarios que procede ante la terminación del vínculo laboral, considera esta Oficina que al referirse la precitada ley a que el pagador tiene el deber de retener o efectuar los descuentos sobre las 'sumas de dinero que haya de pagar a sus asalariados' se puede abarcar en tan amplio concepto todos los emolumentos que reciba el trabajador como consecuencia de la terminación de su contrato de trabajo, sea que los mismos constituyan salario o no.

No obstante lo expuesto, es preciso tener en cuenta que la Ley 1429 del 29 de diciembre de 2010, por la cual se expide la ley de formalización del empleo, establece en su artículo 18 que es prohibido para el empleador deducir, retener o compensar suma alguna del salario, sin orden suscrita por el trabajador, para cada caso, o sin mandamiento judicial. Sin embargo, debe resaltarse que 
la norma aplica respecto de créditos distintos de los obtenidos a través de una libranza, figura que es posterior y cuya regulación es de aplicación preferente cuando el crédito se adquiera bajo esta modalidad; de tal manera que si frente al cambio del pagador, el beneficiario puede mantener la continuidad en el pago de la obligación, podría continuar pagando a través del nuevo pagador; por el contrario, el empleador deberá girar al operador las sumas adeudadas de los salarios y prestaciones del empleado, al momento de la liquidación.

Todo lo anterior, pone de presente que el concepto de salario para el tema de los descuentos directos se debe entender en sentido amplio, es decir, todo pago que recibe el empleado como contraprestación por la actividad desarrollada.

\begin{abstract}
¿Está limitado el número de operaciones de libranza que se pueden realizar?
Dicha discusión fue introducida en la propuesta del ponente en la Primera Ponencia de la Cámara, reseñada en la Gaceta del Congreso No. 810 de 2010, en virtud de la cual se adicionó al artículo 3 el numeral 6 que expresaba: "6. Que no sobrepase en forma simultánea un número máximo de (2) dos créditos de libranza por beneficiario"8. Para evitar así la proliferación descontrolada de la libranza. Sin embargo, finalmente, esta no se limitó a un número de operaciones de libranza para un mismo beneficiario, ni tampoco se excluyó a las personas que devengan un salario mínimo de la posibilidad de suscribir libranzas, pero se estableció un límite al descuento máximo a ejecutar, del $50 \%$ del salario neto que se puede disponer mediante dicha operación?
\end{abstract}

\title{
¿Es la libranza un descuento o un embargo? ¿Qué sucede cuando se decreta un embargo en vigencia de una libranza?
}

Según López Blanco (2016), el embargo es una medida cautelar. Entiende como medida cautelar.

(...) eminentemente accesorio e instrumental, sólo busca, en la mayoría de los casos pero no exclusivamente, asegurar el cumplimiento del derecho solicitado por el demandante, [en] caso de que se profiera decisión que acepte sus pretensiones, impedir para él más perjuicios de los que de por sí le ha ocasionado el demandado al constreñirlo a acudir a la administración de justicia. (p.1076).

Parafraseando a Trujillo Londoño (2014) las medidas cautelares y, por ende, el embargo, tienen como objetivo lograr el resultado de una sentencia que en sistemas judiciales como el colombiano, puede abarcar gran tiempo (p.180). Se caracteriza por ser un acto jurisdiccional, instrumental, legal y provisional (López Blanco, 2016, p.1076 y López Blanco, 2017, p.965).

La Corte Constitucional en sentencia C-054 de 1997 MP. Antonio Barrera Carbonell, caracteriza las medidas cautelares como aquellas que permiten garantizar el ejercicio de un derecho, impedir que se modifique la situación de hecho o de derecho, asegurar los resultados de una decisión judicial. En suma, "proteger de manera provisional y mientras dura el proceso, la integridad de un derecho que es controvertido en ese mismo proceso"

8. En atención a la solicitud realizada por la ANDI “Sobre la precisión en cuanto al número de créditos comprendidos por la libranza regulada por ley, la ANDI considera conveniente establecer límite, referido al número de créditos que pueden quedar comprendidos por el mecanismo de la libranza regulada por ley. Para la ANDI, ese límite de créditos comprendidos por el mecanismo de la libranza regulada por Ley debe ser de 2. Este límite impide que la proliferación de libranzas haga que el mecanismo sea oneroso en extremo." Gaceta Congreso de la República de Colombia No. 801 de 2010.

9. Gaceta Congreso de la República de Colombia No. 964 de 2011 Senado y 966 de 2011 Senado. 
En concreto sobre el embargo, López Blanco (2016) afirma:

(...) la orden que se emite en una providencia judicial y tiene la virtualidad de poner los bienes fuera de comercio cuando se toma nota del mismo por el funcionario público o privado a quien va dirigida, ejemplo el registrador de instrumentos público cuando recibe el oficio decretando el embargo de un bien inmueble, o el funcionario del banco privado cuando el oficio que recibe ordena la cautela respecto de los saldos en una cuenta bancaria. (p. 1082)

En el mismo sentido Escobar Álzate (2014) al expresar que, "Consiste en la orden impartida por un funcionario judicial o administrativo, en virtud del cual se sustrae un bien fuera del comercio, con el objeto de garantizar el cumplimiento de una obligación." (p. 277)

En suma, el embargo proviene de una orden judicial y está revestida con un carácter de obligatoriedad, por lo que debe ser cumplida por quien tenga la función de pagador de la empresa donde labora el trabajador, inclusive con la oposición de este último. En contraste, el funcionamiento de la figura de la libranza radica en la autorización voluntaria del beneficiario a su AFP o empleador, para descontar de su salario, de forma periódica, una suma de dinero que a su vez será trasladada a la entidad operadora.

De forma magistral y completa, la Corte Constitucional en Sentencia T-168 de 2016, magistrado ponente Gabriel Eduardo Mendoza Martelo, agrupa las diferencias antes reseñadas así:

\begin{tabular}{|c|c|c|}
\hline Característica & Descuento por embargo & Descuento por libranza \\
\hline Opera por & Orden judicial. & $\begin{array}{l}\text { Autonomía del trabajador y/o } \\
\text { pensionado. }\end{array}$ \\
\hline Fundamento fáctico & Existencia de un proceso ejecutivo. & $\begin{array}{l}\text { Autorización escrita del trabajador y/o } \\
\text { pensionado. }\end{array}$ \\
\hline $\begin{array}{l}\text { Fundamento } \\
\text { jurídico }\end{array}$ & $\begin{array}{l}\text { Código Sustantivo del Trabajo } \\
\text { artículos del } 149 \text { al } 156 .\end{array}$ & Ley 1527 de 2012, artículo 3 núm. 5. \\
\hline Salario mínimo & Es inembargable & Si puede ser embargado. \\
\hline Monto máximo & $\begin{array}{l}\text { La } 5^{a} \text { parte de lo que exceda el } \\
\text { salario mínimo. }\end{array}$ & $\begin{array}{l}\text { El } 50 \% \text { de cualquier tipo de salario, } \\
\text { inclusive el salario mínimo. }\end{array}$ \\
\hline $\begin{array}{l}\text { Límite del } \\
\text { descuento }\end{array}$ & $\begin{array}{l}\text { Que no vulnere el salario mínimo } \\
\text { legal mensual vigente. }\end{array}$ & $\begin{array}{l}\text { Que por lo menos el trabajador y/o } \\
\text { pensionado no reciba menos del 50\% } \\
\text { de su salario o pensión, después de } \\
\text { los descuentos de ley. }\end{array}$ \\
\hline $\begin{array}{l}\text { Excepción al límite } \\
\text { máximo permitido }\end{array}$ & $\begin{array}{l}\text { Cuando se trate de cobros por } \\
\text { obligaciones alimentarias o a } \\
\text { favor de una cooperativa el límite } \\
\text { se puede aumentar hasta el } 50 \% \\
\text { de cualquier salario, inclusive el } \\
\text { salario mínimo?. }\end{array}$ & $\begin{array}{l}\text { No tiene excepción, solo se admite el } \\
\text { máximo permitido. }\end{array}$ \\
\hline $\begin{array}{l}\text { Reglas de prelación } \\
\text { de créditos }\end{array}$ & $\begin{array}{l}\text { El empleador aplicará la orden de } \\
\text { embargo teniendo en cuenta las } \\
\text { reglas de prelación de créditos } \\
\text { ordenada por el juez. }\end{array}$ & $\begin{array}{l}\text { El empleador aplicará los descuentos } \\
\text { directos por nomina al salario del } \\
\text { trabajador según el orden de llegada } \\
\text { de cada una de estas. }\end{array}$ \\
\hline $\begin{array}{l}\text { Facultad para } \\
\text { regular el monto } \\
\text { del descuento }\end{array}$ & $\begin{array}{l}\text { Radica en cabeza del Juez de } \\
\text { Ejecución, mediante el trámite } \\
\text { incidental de regulación de } \\
\text { embargos. }\end{array}$ & $\begin{array}{l}\text { El valor a descontar es el liquidado por } \\
\text { la cooperativa o financiera que otorgó } \\
\text { la libranza; el trabajador o pensionado } \\
\text { autorizará el descuento del mismo. }\end{array}$ \\
\hline
\end{tabular}




\begin{tabular}{|c|c|c|}
\hline Característica & Descuento por embargo & Descuento por libranza \\
\hline $\begin{array}{l}\text { Aplicación práctica } \\
\text { del descuento }\end{array}$ & $\begin{array}{l}\text { El deber de aplicar a la nómina el } \\
\text { descuento por embargo judicial, } \\
\text { radica en cabeza del empleador, } \\
\text { quien está obligado a cumplir } \\
\text { la orden judicial, respetando las } \\
\text { reglas legales de prelación de } \\
\text { créditos. }\end{array}$ & $\begin{array}{l}\text { La obligación de aplicar el descuento } \\
\text { por libranza radica en cabeza del } \\
\text { empleador en virtud de lo reglado } \\
\text { por el artículo } 6^{\circ} \text { de la Ley } 1527 \text { de } \\
2012 \text {, teniendo en cuenta el orden de } \\
\text { prelación legal y el orden de llegada. }\end{array}$ \\
\hline Sanción & $\begin{array}{l}\text { Le corresponderá al empleador } \\
\text { asumir las sanciones a que haya } \\
\text { lugar por incumplimiento de una } \\
\text { orden judicial². }\end{array}$ & $\begin{array}{l}\text { Conforme al parágrafo } 1^{\circ} \text { del } \\
\text { artículo } 6 \text { de la Ley } 1527 \text { de } 2012 \text {, } \\
\text { si el empleador no cumple con la } \\
\text { obligación de realizar el descuento } \\
\text { por libranza (por motivo que le sea } \\
\text { imputable), será solidariamente } \\
\text { responsable por el pago de la } \\
\text { obligación adquirida por el beneficiario } \\
\text { del crédito. }\end{array}$ \\
\hline $\begin{array}{l}\text { Continuidad del } \\
\text { descuento }\end{array}$ & $\begin{array}{l}\text { Una medida de embargo tendrá } \\
\text { continuidad hasta el pago total de } \\
\text { la obligación. } \\
\text { Declarada la terminación del } \\
\text { proceso ejecutivo, eventualmente } \\
\text { el embargo podría tener } \\
\text { continuidad en virtud de la } \\
\text { existencia de remanentes que } \\
\text { sean solicitados como garantía } \\
\text { de un embargo que curse en } \\
\text { otro proceso ejecutivo asignado } \\
\text { al mismo despacho judicial o a } \\
\text { otro juzgado contra el mismo } \\
\text { demandado. }\end{array}$ & $\begin{array}{l}\text { Si el trabajador o pensionado } \\
\text { beneficiario de la libranza cambia } \\
\text { de empleador tiene la obligación } \\
\text { de informar a la entidad financiera, } \\
\text { luego, la autorización escrita del } \\
\text { trabajador garantiza la continuidad } \\
\text { del descuento hasta el pago total de la } \\
\text { obligación a menos que por cualquier } \\
\text { circunstancia el trabajador revoque la } \\
\text { autorización de descuento. }\end{array}$ \\
\hline
\end{tabular}

Cuadro tomado de la sentencia T-168 de 2016, pp. 18 - 22. Tabla 14.

Por lo anteriormente expuesto, no puede entenderse la figura de libranza como un embargo, pues no se cumple con la característica fundamental del mismo, toda vez que no se da por orden judicial sino por autorización del beneficiario a su AFP o empleador para que descuente de su pensión o salario, sin la necesidad de que exista algún tipo de actuación judicial.

Ahora bien, respecto a la orden de embargo al estar en vigencia una libranza, hay que entrar a analizar si se está en presencia de un embargo por cooperativas o deudas alimentarias, o en otro escenario. Frente al segundo evento, se debe estar a lo dispuesto por las normas laborales en el sentido de embargar el excedente del SMLMV en una quinta parte (art. 155 CST). Y en el primero, por deudas con cooperativas y alimentos, dichos embargos desplazarían el pago de la libranza (art. 156 CST). En ambos casos, ante la ausencia de una norma clara en la ley de libranza sobre cómo proceder frente a los eventuales escenarios planteados, la libranza debe ceder a la orden judicial de embargo y proceder a dar aviso a la entidad operadora de libranza sobre la situación; de no ser así, podría utilizarse el descuento directo para evadir otras obligaciones y desconocer las órdenes judiciales. En tal sentido existe en la Superintendencia Financiera de Colombia un procedimiento interno para los créditos de libranza tomados por sus empleados. ${ }^{10}$ Este punto se desarrollará en el siguiente acápite.

10. 4.7. En caso de presentarse embargos judiciales de orden especial (obligaciones alimentarias) o generales (deudas con bancos, facturas, pagarés, etc.) el Coordinador del Grupo de Compensaciones Económicas de las Personas deberá desplazar los pagos en cumplimiento de la normatividad vigente, de lo cual se deberá informar al Funcionario Beneficiario y a la Entidad Operadora, respetando el siguiente orden:

a) Órdenes Judiciales especiales (obligaciones alimentarias)

b) Deudas a favor de Cooperativas y Fondos de Empleados

c) Órdenes judiciales generales (deudas con bancos, facturas, pagarés, etc)

d) Deudas con la SFC 


\section{Decisiones de la Corte Constitucional sobre tibranza en sede de tutela}

La Corte Constitucional ha desempeñado un papel activo en lo relativo a los descuentos directos de salario o pensión, al considerar que el trabajador y los pensionados son propensos a padecer condiciones especiales de vulnerabilidad que pueden ocasionar afectaciones considerables en sus condiciones de vida digna.

Con referencia a la libranza, para efectos de este escrito, se han seleccionado doce sentencias, unas proferidas con anterioridad a la entrada en vigencia de la Ley 1527 de 2012 y otras con posterioridad; se anticipa que la Corte ha sido constante en la protección del deudor y de su mínimo vital ante embargos o descuentos directos. No obstante, con la entrada en vigencia de la ley en mención, introdujo nuevos parámetros. Las sentencias objeto de estudio fueron:

Tabla 15. Resumen sentencias emitidas por la Corte Constitucional

\begin{tabular}{ll}
\hline T-1015 de 2006. & MP. ALVARO TAFUR GALVIS \\
\hline T-664 de 2008 & MP. RODRIGO ESCOBAR GIL \\
\hline T-512 de 2009 & MP. LUIS ERNESTO VARGAS SILVA \\
\hline T-581A de 2011 & MP.MAURICIO GONZÁLEZ CUERVO. \\
\hline T-717 de 2013 & MP. LUIS ERNESTO VARGAS SILVA \\
\hline T-891 de 2013 & MP. LUIS ERNESTO VARGAS SILVA \\
\hline T-864 DE 2014. & MP.GLORIA STELLA ORTIZ DELGADO. \\
\hline T-426 DE 2014 & MP. ANDRÉS MUTIS VANEGAS. \\
\hline T-418 DE 2016 & MP. LUIS GUILLERMO GUERRERO PÉREZ \\
\hline T-168 de 2016 & MP. GABRIEL EDUARDO MENDOZA MARTELO \\
\hline T-510 de 2016 & MP. ALBERTO ROJAS RIOS \\
\hline T-629 DE 2016 & MP. GABRIEL EDUARDO MENDOZA MARTELO \\
\hline
\end{tabular}

Del análisis de las referidas sentencias se extraen varios puntos a tratar, previa enunciación breve del concepto de mínimo vital. En primer lugar, los parámetros para entender y aplicar de forma correcta el límite del 50\% establecido en la Ley 1527 de 2012. En segundo lugar, quién es el responsable de velar por la correcta aplicación del límite. Y, en tercer lugar, cómo debe proceder el empleador con posterioridad a la tutela de los derechos al mínimo vital y vida digna declarados por la Corte cuando los descuentos realizados superan el límite.

El concepto de mínimo vital es la base sobre la cual la Corte genera todas las disertaciones. Es enunciado en la totalidad de las sentencias como el derecho fundamental presuntamente vulnerado a los tutelantes en todas las ocasiones. Y en algunos eventos también el derecho a una vida digna.

En las sentencias T-664 de 2008, T-512 de 2009, T-581A de 2011, T-891 de 2013, T-426 y T-864 de 2014, T-510 y T-629 del 2016, la Corte otorga pautas generales sobre este concepto del mínimo vital. Explica que este debe entenderse no como algo abstracto, sino como algo concreto, puesto que todas las personas no poseen un mínimo vital igual. 
Para dimensionar correctamente el citado derecho, es necesario tener en cuenta que él debe ser considerado frente a un caso en concreto y no en abstracto, lo cual implica una valoración cualitativa, y no cuantitativa del contenido del mínimo vital de cada persona en un determinado caso concreto, de acuerdo con sus condiciones sociales, económicas y personales. (Sentencia T-664 de 2008).

Aspecto que es reiterado en sentencias como la T-891 de 2013 y T-510 de 2016.

El mínimo vital no es únicamente el salario mínimo, aunque tienen estrecha relación con este, por lo que se debe analizar las particularidades de la persona que invoca tal derecho: "En efecto, existen situaciones en las que proteger el salario mínimo de una persona no necesariamente garantiza las condiciones básicas sin las cuales un individuo no podría vivir dignamente." (Sentencia T 426 de 2014). En igual sentido en la sentencia T-891 de 2013 explica "(...) que el mínimo vital no es un concepto equivalente al de salario mínimo, sino que depende de una valoración cualitativa que permita la satisfacción congrua de las necesidades, atendiendo las condiciones especiales en cada caso concreto."

En suma, el concepto de mínimo vital es amplio y debe analizarse en cada particular, porque es una garantía del Estado Social de Derecho para asegurar condiciones de vida digna.

Es un concepto que no solo busca garantizarle al individuo percibir ciertos recursos, sino permitirle desarrollar un proyecto de vida. De allí que también sea una medida de justicia social, propia de nuestro Estado Constitucional. Ello supone mirar a las personas más allá de la condición de individuo o de persona y entenderlas como sujetos activos en la sociedad. En este orden de ideas, aunque el mínimo vital se componga inevitablemente de aspectos económicos, no puede ser entendido bajo una noción netamente monetaria. No se protege solo con un ingreso económico mensual. Este debe tener la virtualidad de producir efectos reales en las condiciones de la persona, de tal manera que no solo le garantice vivir dignamente sino también desarrollarse como individuo en una sociedad. (Sentencia T-426 de 2014).

Para dar inicio a los aspectos antes referenciados, la Corte es consciente de las novedades de la Ley 1527 del 2012 puesto que permite que se hagan deducciones por descuento directo al salario mínimo, sin embargo es clara en que no puede sobrepasar el $50 \%$.

Es necesario señalar que, al tenor de la ley, el límite es el " $50 \%$ del salario neto después de los descuentos de ley", lo que significa que las deducciones de parafiscales no entran a formar parte del monto base para tomar ese $50 \%$. Criterio que no aplica la Corte de forma uniforme, puesto que en algunas sentencias lo aplica (T-510 de 2016) y en otras, toma el salario inicial para calcular el monto (T-426 del 2014). Esto tiene implicaciones para el empleador y el empleado, toda vez que no es lo mismo partir de una salario base de $\$ 828.116$ cuyo $50 \%$ será de $\$ 414.058$, a realizar las deducciones de ley al salario base, para un total de $\$ 757.726$ (disminuyendo un $8.5 \%$ ) cuyo $50 \%$ es $\$ 378.863$. Ya la discusión de sí ese monto puede considerarse un mínimo vital, le corresponde al juez analizarlo para cada caso concreto. 
La Corte enfatiza en que dicho límite es de orden público, por lo que, a pesar de contar con autorización escrita del deudor, no se podrá disponer de un monto superior al mismo.

Con respecto a las medidas cautelares sobre salarios y pensiones, y en general sobre los descuentos efectuados a dichas prestaciones, la jurisprudencia constitucional ha precisado que ellos son permitidos, siempre y cuando respeten la regulación especial en la materia, y no sobrepasen los topes máximos previstos en ella. Así, esta Corporación ha precisado que estas normas no tienen un carácter dispositivo, sino que son de orden público ${ }^{11}$. (Sentencia T-664 de 2008),

Para completar el primer aspecto referido, la sentencia T-891 de 2013 es fundamental, puesto que la Corte se da a la tarea de precisar con claridad unos parámetros en los que se debe aplicar la flexibilización de los criterios que trae la Ley 1527 de 2012 para la celebración y ejecución de la libranza.

Resultado de la aplicación del artículo 53 constitucional se precisa que: “En efecto, la mencionada norma establece el principio de irrenunciabilidad de los derechos. Este mandato significa que bajo ninguna circunstancia, el trabajador podrá negociar, transigir, desistir, renunciar, etc., a un derecho que la ley laboral establezca como mínimo e irrenunciable" (Sentencia T-891 de 2013)

Según la Corte, la razón de que la ley proteja el salario mínimo del trabajador es muestra de la importancia de la irrenunciabilidad del mismo, lo que constituye una garantía mínima del trabajador. En la misma sentencia expone que:

(...) el artículo 53 Superior establece que el legislador debe prever ciertos principios inquebrantables a la hora de regular derechos laborales. Uno de ellos es el de la "irrenunciabilidad a los beneficios mínimos establecidos en normas laborales" y "remuneración mínima vital y móvil, proporcional a la cantidad y calidad de trabajo". Lo anterior significa que el legislador reglamenta derechos laborales, debe definir cuales entiende como irrrenunciables los cuales gozarán de una protección especial por parte de todos los órganos del Estado. Uno de ellos es el salario mínimo.

Finaliza con una aclaración sobre la intención de no inutilizar la libranza, sino lograr una armonización entre la libranza y los derechos fundamentales:

Eso no quiere decir que la libranza de ahora en adelante carezca de todo objeto. Flexibilizar la aplicación rígida del artículo tercero numeral quinto de la ley 1527 de 2012, garantiza la supremacía de los derechos constitucionales pues permite los descuentos del (50\%) del salario, siempre y cuando al gravarse el salario mínimo, no se ponga en riesgo o lesionen los derechos fundamentales del trabajador. En síntesis, en las libranzas el trabajador podrá autorizar el descuento de máximo el cincuenta (50\%) de su salario de conformidad con el artículo tercero numeral quinto de la ley 1527 de 2012. Pese a ello, de acuerdo con las reglas fijadas por la Corte, cuando se lesionen los derechos al mínimo vital y a la vida digna, no es posible afectar el salario mínimo. Ello dependerá de los hechos particulares del caso los cuales serán evaluados por el juez de tutela. Cuando esto ocurra, el empleador deberá priorizar las deudas de la

$\overline{\text { 11. Reiterado en sentencias }}$ T-891 de 2013, T-426 de 2014, T-512 de 2009. T-581A de 2011, T-516 de 2016 y T-629 de 2016). 
más antigua a la más reciente a fin de satisfacerlas completamente. (Sentencia T-891 de 2013. Subrayado fuera del texto original).

En concreto, los parámetros son:

En primer lugar (i), los descuentos directos deben respetar los máximos legales autorizados por la ley. En segundo lugar (ii), existe un mayor riesgo de afectar el derecho al mínimo vital cuando (ii.1) entre el salario y la persona exista una relación de dependencia, es decir, que sea la única fuente de ingresos; (ii.2) cuando su familia dependa de sus ingresos y finalmente; (ii.3) cuando se trate de personas de la tercera edad. Adicionalmente (iii), de ninguna manera es posible descontar más allá del salario mínimo legal vigente, salvo que se trate de embargos por deudas con cooperativas y por alimentos. En esos casos, su máximo será del cincuenta por ciento (50\%). Por su parte, (iv) el responsable de regular los descuentos es el empleador o pagador según el caso. Finalmente, (v) en los descuentos directos por libranza se puede descontar hasta el cincuenta por ciento (50\%) del salario (según el caso), siempre y cuando, si se afecta el salario mínimo, no se ponga en riesgo o lesionen los derechos al mínimo vital y a la vida digna de la persona de acuerdo con las reglas fijadas por esta Corporación ${ }^{12}$. (Sentencia T-891 de 2013)

Con referencia al segundo aspecto, es pacífica la posición respecto a la responsabilidad de que el empleador o pagador es quien debe vigilar que los descuentos no superen el límite permitido por la ley. Así lo reseña el punto IV de las pautas para la correcta aplicación de la libranza "(iv) el responsable de regular los descuentos es el empleador o pagador según el caso". (Sentencias T-891 de 2013, T-426 de 2014. T-168, T-516 y T-629 de 2016).

Es posible catalogar como un segundo control sobre la libranza el realizado por el pagador, ya que la entidad operadora de libranza debe realizar un estudio sobre la capacidad de pago y de endeudamiento del deudor, primer filtro; luego se suscribe el convenio de recaudo con el pagador, y es ahí donde el empleador debe garantizar, por tener información de primera mano, que no se supere el límite que enmarca la ley y no se afecte el mínimo vital del deudor.

Para culminar, respecto al tercer aspecto, las decisiones de la Corte no dejan entrever una única línea en cuanto al procedimiento que debe realizar el pagador cuando se han acumulado descuentos y embargos que superan el $50 \%$. Así sucede en los casos de las sentencias T-512 de 2009 y T-581A de 2011, en las cuales no hace mención alguna al respecto, mientras que en otros, le da prevalencia a los embargos, por lo que la libranza queda sujeta a disposición del salario restante hasta que se cumpla el límite del 50\%, tal como lo hizo en la sentencia T-426 de 2014.

En contraste con lo anterior, sólo a partir del año 2016 la Corte plantea un escenario claro para el proceder del pagador. Son dos los casos que se pueden presentar: i) sólo concurren libranzas o descuentos directos, el criterio de prevalencia es el principio general de quien es primero en el tiempo, es primero en el derecho y, ii) en caso de concurrir embargos y libranza, se dará prevalencia a las órdenes judiciales. 
Respecto al primer caso, expresa:

En las libranzas, el trabajador o pensionado podrá autorizar el descuento de máximo el cincuenta (50\%) de su ingreso de acuerdo con el artículo $3^{\circ}$, numeral $5^{\circ}$, de la Ley 1527 de 2012. No obstante, deben tenerse en cuenta las reglas fijadas por la Corte, las cuales precisan que cuando se lesionen los derechos al mínimo vital y a la vida digna, no es posible afectar el salario mínimo, lo cual dependerá de los hechos particulares del caso, los cuales serán analizados por el juez de tutela. Cuando esto ocurra, el empleador o pagador priorizará las deudas, de la más antigua a la más reciente a fin de satisfacerlas completamente." (Sentencia T-864 de 2014 y T-168 de 2016).

Con relación al segundo caso, me permito para mayor claridad citar en extenso lo que la Corte expone:

Como lo establece la doctrina constitucional en mención, el servidor judicial no tiene herramientas jurídicas que le permitan limitar las deducciones por libranzas. Tampoco se podría supeditar o condicionar jurídicamente la emisión de una orden judicial de embargo, según el número de descuentos que hubiere autorizado el trabajador en los casos de concurrencia de descuentos. Lo anterior por cuanto las medidas cautelares en los procesos ejecutivos conforme a las reglas establecidas en la normativa procedimental, tienen como sustento: (i) Un justo título en el que consta una obligación, clara, expresa y exigible; (ii) la orden de embargo es plena, es decir, no puede estar condicionada o limitada más que por lo establecido en la ley procesal (orden de prelación de créditos, pago de caución y juramento según el caso). Igualmente incide: (iii) El tipo del título en ejecución que puede ser (simple o complejo); (iv) el monto total de la obligación en cobro judicial; (v) el tipo y número de embargos ordenados en el proceso ejecutivo (embargos de: salarios, bienes muebles, bienes inmuebles, así como embargos de títulos judiciales y/o remanentes constituidos en otros procesos ejecutivos (en los que proceda la conversión y/o fraccionamiento del mismo, según el caso).

Por todo lo expuesto, al juez de ejecución le asiste dentro del trámite del proceso ejecutivo, la facultad de (i) regulación del monto y clases embargos (ii) ordenar el pago de las deudas que se estén cobrando dentro de un proceso ejecutivo, de acuerdo con la clasificación y preferencia que para tales efectos ha fijado la ley, empezando por los créditos de primera clase y hasta donde se alcance.

Es así, como la Ley 1527 de 2012, no estableció en cabeza del juez la obligación de regular los descuentos por libranzas, por cuanto estos dependen exclusivamente de la autonomía del trabajador, fundada en la orden escrita que este entregue a su empleador para efecto de la aplicación de estos descuentos.

Conforme a la normativa aplicable, se desprende de lo analizado, que le asiste al empleador una obligación legal, clara y ligada indisolublemente al respeto de los derechos fundamentales de los trabajadores, y es la de priorizar y computar los descuentos que le aplicará a los salarios de los trabajadores, por una parte, los que tienen origen en una orden judicial según las reglas de prelación de créditos que el juez señale en el oficio de embargo y, por otra parte, los autorizados expresamente por el trabajador. Para todos el empleador debe tener en cuenta, (i) el orden de llegada, es decir, corresponde aplicar el 
primer descuento ordenado judicialmente o autorizado por el trabajador, según las reglas de prelación de créditos, y los demás, deben esperar su turno hasta el pago de la primera deuda, y así sucesivamente; (ii) la aplicación de los descuentos no deberá afectar el derecho fundamental al mínimo vital del trabajador, cuando se confronte casos de trabajadores en los que el salario constituye la única fuente de subsistencia y la de su núcleo familiar a cargo. (Sentencia T-168 de 2016).

De la postura reseñada, se infiere la prevalencia de los embargos sobre los descuentos por libranza al tener en cuenta varios aspectos, entre ellos: i) los requisitos que se deben cumplir para la emisión de un mandamiento de pago, esto es, una obligación expresa, clara y exigible ${ }^{13}$, ii) la imposibilidad del juez de regular los descuentos autorizados por el beneficiario sin solicitud previa de las partes que intervienes en la libranza y iii) la naturaleza coactiva del embargo, es decir, contrario a lo que sucede con la libranza donde es un acto de mera liberalidad del beneficiario, en los embargos existe un incumplimiento previo del deudor que hace que el embargo sea una orden judicial. No obstante, el operador de la libranza podrá acudir al proceso ejecutivo ante el eventual incumplimiento del beneficiario.

\section{Conclusiones}

La libranza tiene un fin legítimo, toda vez que pretende dinamizar la economía y facilitar la adquisición y pago de bienes y servicios. Sin embargo, para poder hablar de libranza es necesario estar en presencia del convenio de recaudo, puesto que este es el elemento central de dicha convención, en el que se regula lo relativo a la forma de pago, la logística y la manera en que el descuento llegue a su destinatario final.

El descuento directo es el concepto genérico por medio del cual se autoriza una deducción del salario, pensión u honorarios como forma de pago. Pero no todo descuento implica una operación de libranza ya que, según la Superintendencia de Sociedades, de hacerse con los empleados a cargo y como una actividad secundaria que no genera la mayoría de ingresos de la sociedad, no es necesario dar cumplimiento a los requisitos de los operadores de libranza. Sin embargo, es necesario respetar en todo momento lo relativo al límite del $50 \%$ del salario o remuneración como norma de orden público.

Respecto a las cifras obtenidas de los fondos de pensiones, es importante resaltar que el mayor porcentaje de las pensiones afectadas con libranza corresponde a las de vejez. A manera de ejemplo, para Colfondos, de las pensiones afectadas con libranza, el 55,53\% son pensiones de vejez y para Colpensiones del total afectado con libranza, el 82,72 \% corresponde a pensiones de vejez. Lo anterior pone de presente que gran parte el mercado de la libranza va dirigido a personas mayores quienes son más vulnerables frente a una afectación del mínimo vital.

Con relación al concepto amplio de salario, en el que la liquidación de las prestaciones sociales, una vez culmine la relación laboral, también es objeto del descuento directo, se propone que no debería permitirse este, toda vez que el operador de libranza tiene la oportunidad de solicitar el descuento a cualquier empleador que tenga el deudor con la misma autorización inicial y este no podría negarse. Más aún, al tener en cuenta que la liquidación final tiene como propósito amparar los gastos básicos en la transición de un empleo a otro por parte del empleador, para garantizar unas condiciones básicas y dignas de vida. 
De la jurisprudencia reseñada se desprende la importancia del papel del pagador, ya que es quien realiza los descuentos y remite a la entidad operadora. Esta responsabilidad se aumenta al tener en cuenta que, de no realizar los descuentos de forma acorde, responde solidariamente con el deudor ante la entidad operadora. No obstante, en los casos en que los descuentos afecten el mínimo vital del deudor, este último carece de un mecanismo eficaz para el control de los descuentos, es decir, la ley de libranza no plantea un mecanismo mediante el cual el deudor solicite un ajuste en los descuentos, ante lo cual puede acudir al derecho de petición y ante la negativa, interponer una acción de tutela para la protección de su mínimo vital.

Como tema transversal, la Corte en sus sentencias expone que el mínimo vital es el eje para analizar la correcta aplicación de la libranza. Sin embargo, este es un concepto que por la obligatoriedad de su análisis para el caso en concreto puede difuminar el límite del 50\% autorizado para el descuento. Así sucedió en el caso reseñado en la sentencia T-510 de 2016, donde consideró que, a pesar de no superarse el límite legal, se estaba afectando el mínimo vital del tutelante. En palabras de la Corte:

“La pensión equivale a seis cientos cuarenta y cuatro mil trescientos cincuenta pesos ( $\$$ 644.350); a título de descuento del aporte al sistema de salud, se retienen setenta y siete mil trescientos veinte dos pesos (\$77.322). De esta manera, el cincuenta por ciento (50\%) del valor neto de la pensión es doscientos ochenta y tres mil quinientos catorce pesos (\$283.514). Tras el descuento de la cuota mensual, el accionante recibe doscientos noventa mil, novecientos veinte ocho pesos (\$290.928). Es decir que, prima facie, el señor Uribe Blanco, recibe siete mil cuatrocientos catorce pesos (\$7.414) más del límite previsto por la ley.

No obstante, para la Sala Octava de Revisión de tutelas de la Corte Constitucional no basta que el descuento que se realiza a la mesada pensional del señor Uribe Blanco supere en siete mil pesos el límite legal, dado que, en todo caso: (i) la curadora del peticionario, y todo el núcleo familiar integrado por dos personas en condición de discapacidad, solo recibe doscientos noventa mil pesos, valor claramente insuficiente para atender las condiciones de vida digna de dos personas sujetos de especial protección constitucional; y (ii) resulta indudable, que el contrato de crédito de consumo y servicios celebrado entre Flavio Uribe Blanco y ASFAMICOOP no debió celebrarse, en virtud a su condición de interdicción."

Lo que ejemplifica, de forma clara, la postura de la Corte Constitucional y la necesidad de analizar el mínimo vital para el caso concreto.

Del concepto emitido por la Superintendencia de Sociedades donde refiere una interdependencia entre el contrato de mutuo celebrado entre el deudor y la entidad operadora de libranza y el convenio de recaudo celebrado entre la operadora de libranza y el pagador, es conveniente plantear la posibilidad de que se analice dicha situación a la luz de la conexidad contractual. Dicha teoría plantea que en escenarios en los que se celebre entre sujetos distintos una pluralidad de contratos que aunque independientes tengan relación y una causa supracontractual, los efectos y vicisitudes que tenga un contrato, pueden repercutir en el otro. Como referencias para un eventual estudio posterior, confrontar con López Frías (1994), Zapata Flórez (2015), Cataño y Wills, (2016) y sentencias de la Corte Suprema de Justicia, Sala Casación Civil como: SC6709-2015 del 28 de mayo de 2015, radicado n 11001-31-03-031-2000-00253-01, 
MP. Jesús Vall De Rutén Ruiz y sentencia SC18476-2017 del 15 de noviembre de 2017 con radicado n. ${ }^{\circ}$ 68001-31-03-001-1998-00181-02, MP. Álvaro Fernando García Restrepo.

\section{Referencias}

ASOBANCARIA. (2016). La Banca Colombiana en 2015. Recuperado de: https:// www.asobancaria.com/wp-content/uploads/2016/06/Informe-de-Tipificación-2015-Version-Web.pdf

ASOBANCARIA. (2016). Semana Económica 2016. La libranza en Colombia, más allá de Estraval. Recuperado de: https://www.asobancaria.com/semanseconomicas/Sem- 1056.pdf

Banco de la República. (2017). Informe especial de estabilidad financiera. Riesgo de Crédito de septiembre de 2017. Bogotá D.C.

Cataño, S \& Wills L, (2016) La conexidad contractual y los efectos relativos de los negocios jurídicos aplicados a los contratos de paquetes turísticos en Colombia. Vniversitas. 65 (132), p. 59-88.

Congreso de la República de Combia, (2011). Gaceta 916. Recuperado de: http://svrpubindc.imprenta.gov.co/senado/index2.xhtml?ent=Senado\&fec $=30-11-2011 \&$ num $=916 \&$ consec $=31116$

Corte Suprema de Justicia. Sala de Casación Civil. Proceso SC6709-2015, radicado n 11001-31-03-031-2000-00253-01,(MP. Jesús Vall De Rutén Ruiz, 28 de mayo de 2015).

Corte Suprema de Justicia. Sala de Casación Civil. Proceso SC18476-2017, radicado n. ${ }^{\circ}$ 68001-31-03-001-1998-00181-02, (MP. Álvaro Fernando García Restrepo, 15 de noviembre de 2017.

Corte Constitucional. Sentencia C-054 de 1997. (MP. Antonio Barrera Carbonell. Febrero 06 de 1997.

Corte Constitucional. Sentencia T-1015 del 2006. (MP. Álvaro Tafur Galvis. Noviembre 30 de 200.

Corte Constitucional. Sentencia T-664 del 2008. (MP. Rodrigo Escobar Gil. Julio 01 de 2008).

Corte Constitucional. Sentencia T-512 del 2009. (MP. Luis Ernesto Vargas Silva. Julio 30 de 2009).

Corte Constitucional. Sentencia T-581A del 2011. (MP. Mauricio González Cuervo. Julio 25 de 2011).

Corte Constitucional. Sentencia C-015 de 2013. (MP: Mauricio González Cuervo. Enero 23 de 2013).

Corte Constitucional. Sentencia C-085 de 2013. (MP: Nilson Pinilla Pinilla. Febrero 20 de 2013) 
Corte Constitucional. Sentencia C-122 de 2013. (MP: Mauricio González Cuervo. Marzo 13 de 2013).

Corte Constitucional. Sentencia C-751 de 2013. (MP: Luis Guillermo Guerrero Pérez. Octubre 30 de 2013).

Corte Constitucional. Sentencia T-717 de 2013. (MP. Luis Ernesto Vargas Silva. Octubre 17 de 2013).

Corte Constitucional. Sentencia T-891 de 2013. (MP. Luis Ernesto Vargas Silva. Diciembre 03 de 2013).

Corte Constitucional. Sentencia T-426 de 2014. (MP. Andrés Mutis Vanegas. Julio 02 de 2014).

Corte Constitucional. Sentencia T-864 de 2014. (MP. Gloria Stella Ortiz Delgado. Noviembre 12 de 2014).

Corte Constitucional. Sentencia T-168 de 2016. (MP. Gabriel Eduardo Mendoza Martelo. Abril 11 de 2016).

Corte Constitucional. Sentencia T-418 de 2016. (MP. Luis Guillermo Guerrero Pérez. Agosto 09 de 2016).

Corte Constitucional. Sentencia T-510 de 2016. (MP. Alberto Rojas Ríos. Septiembre 16 de 2016).

Corte Constitucional. Sentencia T-629 de 2016. (MP. Gabriel Eduardo Mendoza Martelo. Noviembre 15 de 2016).

Corte Constitucional (2018). Comunicado No. 15 del 02 de Mayo. Recuperado de: http://www.corteconstitucional.gov.co/comunicados/No.\%2015\%20comunicado\%2002\%20de\%20mayo\%20de\%202018.pdf

Corte Constitucional. Sentencia C 032 de 2018. (MP: José Fernando Reyes Cuartas. Mayo 02 de 2018).

Dinero. (2017). 3 de los directivos de Estraval aceptan cargos por escándalo de libranzas. Recuperado de: https://www.dinero.com/inversionistas/articulo/directivos-de-estraval-aceptan-cargos-por-libranzas/248936

El Espectador. (2017). El top de "tumbados" en Estraval. https://www.elespectador. com/noticias/judicial/el-top-de-tumbados-en-estraval-articulo-680315

Escobar Álzate, J. (2014). Nociones Básicas del Derecho Procesal en el Código General del Proceso. Ibagué: Universidad de Ibagué.

López Blanco, H. (2016) Código General del proceso parte general. Bogotá D.C: Dupre Editores.

López Blanco, H. (2017) Código General del proceso parte especial. Bogotá D.C: Dupre Editores. 
López Cárdenas, J. (2015). Derecho Laboral Individual. Bogotá D.C: Grupo Editorial Ibañez.

López Frías, A. (1994), Los contratos conexos, Barcelona, José María Bosch

Ministerio de Trabajo (2013). Oficio 193287.

Procuraduría General de la Nación. (2017). ABC de las libranzas en Colombia. Bogotá D.C. Recuperado de: https://www.procuraduria.gov.co/portal/media/file/ABC-Libranzas-v2.pdf

SEMANA. (2018). A la venta cartera de libranzas para pagar a afectados de Estraval. https://www.semana.com/Item/ArticleAsync/554546?nextld=554559

Superintendecia Financiera de Colombia. (2008). Concepto 2008038709-002.

Superintendencia Financiera de Colombia. (2013). Concepto 2012101834-001

Superintendencia de Sociedades. (2013). Oficio 220-121536

Superintendencia de Sociedades. (2015). Oficio 220-100622

Superintendencia de Sociedades. (2015). Oficio 220-0002840

Superintendencia de Sociedades. (2016). Oficio 220-196557.

Superintendencia de Sociedades. (2017). Oficio 220-168212.

Trujillo Londoño, F. J. (2014). Las medidas cautelares en el contexto del Código General del Proceso. Criterio Jurídico Garantista, N 11, Jul - Dic. P 176 - 185.

Zapata Flórez, J. (2015). La causa como elemento estructural de la contratación conexa. Revista de Derecho Privado, No. 54, julio-diciembre, 2015, pp. 1-20. Bogotá: Universidad de Los Andes Bogotá. 